\title{
Analysis on the Influence of the Establishment of Hainan Free Trade Zone on the Economic Cooperation between Guangxi and ASEAN
}

\author{
Fan $\mathrm{Li}^{1}$ \\ ${ }^{1}$ School of Statistics, \\ Shanxi University of Finance and Economics \\ Taiyuan, Shanxi, China
}

\author{
$\mathrm{Nan} \mathrm{Xu}^{2}$ \\ ${ }^{2}$ Faculty of International Trade, \\ Shanxi University of Finance and Economics \\ Taiyuan, Shanxi, China
}

\begin{abstract}
In October 2018, the CPC central committee and the state council issued the guidance on supporting Hainan to comprehensively deepen reform and opening up, marking a new step in the process of opening up to the outside world. The construction of Hainan pilot free trade zone has brought a series of challenges and opportunities to the development of Guangxi Beibu Gulf economic zone across the sea (bay). [1]The construction of Hainan free trade zone will be conducive to bringing into play the coordinating role of the two places, strengthening the interconnection between the two places, promoting innovation and promoting the development of high and new technologies. The CPC central committee fully supports Hainan to deepen reform and opening up, which is unparalleled in Guangxi. Therefore, Guangxi must seize a new round of opportunities, face up to the challenges from Hainan free trade zone, optimize development structure, promote industrial transformation and upgrading, and strengthen the trade links and connectivity with ASEAN, so as to push the economic development of Guangxi to a new level.
\end{abstract}

Keywords-Guangxi-asean free trade area; Hainan free trade zone; Beibu gulf economy

\section{INTRODUCTION}

This year marks the 40th anniversary of China's reform and opening up. As the largest provincial special economic zone in China, hainan province, which was born out of the reform and opening up, has been integrated into the chinaasean free trade area and the northern economic circle. By comparing the advantages and disadvantages of hainan and guangxi in china-asean economic relations, we will make a reasonable analysis of the opportunities and challenges faced by guangxi, and put forward effective Suggestions through comparison, so as to make them conform to China's economic reform and opening-up policy and better serve the economic society under socialism with Chinese characteristics [3].

\section{THE DEVELOPMENT STATUS OF THE TWO FREE TRADE ZONES}

\section{A. Foreign trade status of Guangxi}

1) Guangxi's foreign trade is generally on the rise and its trade structure is improving day by day.

The following will take the data from 2013 to 2016 as an example to analyze the development status of foreign trade between guangxi and asean. As can be seen from the figure below, since 2013, the foreign trade structure of guangxi has generally been in a balanced state, with the proportion of imports and exports floating within 10 percentage points of $50 \%$. Since 2015 , the range has narrowed to less than five percent. The structure of imports and exports has been constantly improved, and trade has developed in a balanced way. It can be seen that guangxi attaches great importance to foreign trade, and also reflects the importance of foreign trade to the economic development of guangxi [2].

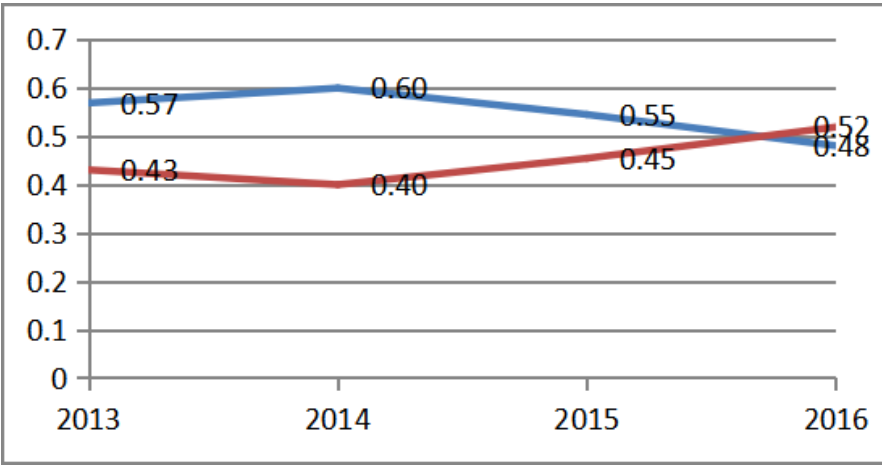

Fig. 1 The structure of Gangxi's foreign trade

From the figure below, we can see that from 2013 to 2015 , guangxi's total import and export volume and the year-on-year figure of guangxi's import and export volume increased significantly, remained at a high level and showed an upward trend, reaching the highest level in 2015, the total import and export volume reached 317042.15 million yuan, an increase of $28 \%$ compared with the previous year. However, 2016 was obviously a period of adjustment. The total amount decreased slightly but remained relatively high, decreasing by only $1 \%$ compared with 2016. To some extent, it reflects that guangxi is adjusting its industrial structure and improving the industrial balance of import and export trade [4]. 


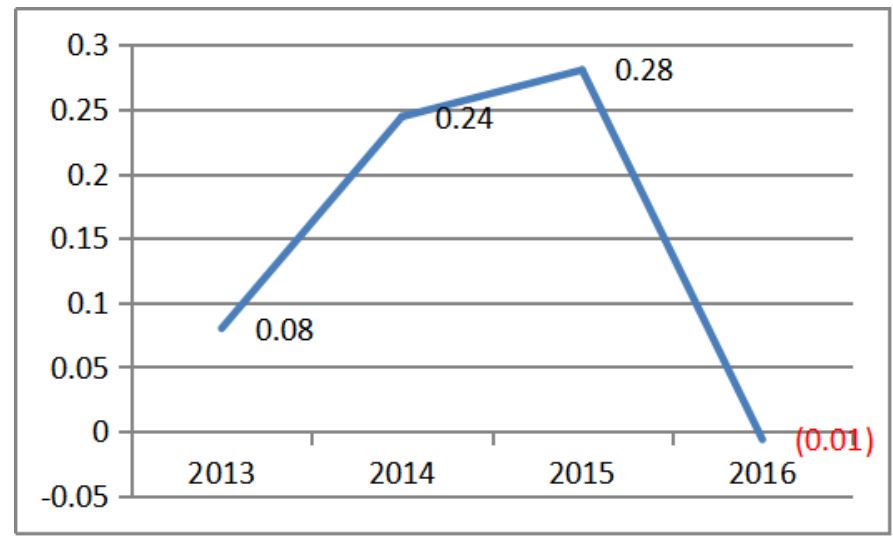

Fig. 2 Guangxi imports and exports year-on-year

2) The bilateral trade with ASEAN has increasingly become the top priority in Guangxi's foreign trade.

As an important foreign trade area in guangxi, the trade volume of asean has been greatly increased, and the trade structure of both sides has been constantly optimized. In 2012 and 2014, guangxi's import volume was much smaller than its export volume, and the total import volume in 2014 only accounted for $16.5 \%$ of its export volume. However, this situation improved somewhat in 2015, especially in 2016. Although the total amount of import and export did not increase, the structure of import and export was significantly improved, and almost the import and export reached an equilibrium state. It can be seen that guangxi attaches great importance to asean as an important trade area and its improvement.

3) China's foreign trade structure with ASEAN has been constantly improved, and both competition and complementarity coexist.

Comparison in 2016 in guangxi and asean bilateral trade volume larger several products, you can see, the mechanical and electrical products and the import and export of high-tech products at the same time occupies the important position, the two sides can be present competition in this area, and according to the apparel and clothing accessories and water seafood exports and imports of soya beans and crude oil, the two sides on the industrial structure of complementarities exist at the same time. On the whole, the bilateral trade between guangxi and asean presents a good development trend.

TABLE I

AMOUNT OF MAJOR IMPORT AND EXPORT COMMODITIES

\begin{tabular}{|l|l|l|l|}
\hline Amount of major import and export commodities & \multicolumn{2}{l|}{ Amount (ten thousand yuan) } \\
\hline export commodities & Amount (ten thousand yuan) & Imported goods & 1683970 \\
\hline Mechanical and electronic products & 6126798 & soybean & 912956 \\
\hline High-tech products & 2374451 & Crude oil & \\
\hline Clothing and accessories & 1218396 & Mechanical and electronic products & 3349290 \\
\hline Aquatic products and their products & 252073 & High-tech products & 2494820 \\
\hline
\end{tabular}

\section{B. Advantages analysis of Guangxi's development}

(1)Guangxi has a profound cooperative relationship with asean, and the route of guangxi's free development has been formed.

(2)Guangxi enjoys cultural affinity with asean countries [5]. Its abundant south Asian tropical agricultural and forestry resources, Marine resources, mineral resources, water energy resources and tourism resources are obviously complementary to asean countries in terms of resource types and industrial structure, and the two sides have huge potential for all-round and in-depth economic cooperation. Besides, guangxi enjoys preferential policies such as coastal region opening up policy, western development policy and regional ethnic autonomy policy.

(3)Guangxi enjoys advantageous geographical location, convenient trade and transportation.

(4)Guangxi is a good geographical location, south of the beibu gulf economic zone, north of the Chinese mainland, west of asean, east of guangdong, China is the only province with both land and sea access to asean, China's most convenient access to asean. Therefore, there are various transportation modes that guangxi can use in its trade with asean [6]. First of all, since guangxi has a coastline of 1,629 kilometers along the coast, river and border, Marine transportation can be realized by using three good ports of fangcheng port, qinzhou port and beihai port. In addition to guangxi's natural water resources and the increasingly developing shipping industry in the later period, the Marine transportation of guangxi has a hard condition. Second, guangxi is the junction of south China economic circle, southwest economic circle and asean economic circle. At present, guangxi's railway network has formed a layout of "three ports and one line", becoming an important transportation hub of china-asean free trade area.

\section{ANALYSIS OF CHALLENGES TO GUANGXI CAUSED BY THE CONSTRUCTION OF HAINAN FREE TRADE ZONEE}

\section{A. Policy positioning gap is large, the degree of attention is different}

In October 2018, the state council issued the approval of the state council on agreeing to establish the China (hainan) pilot free trade zone. Whereas in guangxi, as a result of the beibu gulf region the industry foundation is weak, so most coastal cities is not able to make full use of the advantages of the port entrepot trade and industry, and the country will strategically upgraded to face the world of the free trade area of hainan province (port), it will be at the policy level by state more seriously, and from the point of foreign trade data of hainan province, hainan province, the main trade partners for the association of south-east Asian nations (asean), the 
European Union and the United States, highlighted when free trade port, hainan import and export trade with asean region will be increased to challenge with the important role of asean trade in guangxi.

\section{B. Hainan province attracts enterprises to settle in and the} drainage effect is obvious while Guangxi loses the advantage

In terms of trade between China and asean, guangxi has been the largest trading partner between China and asean for 15 consecutive years, and the beibu gulf economic zone located in the south of guangxi is undoubtedly the most attractive carrier of the market. With the establishment of hainan free trade zone, hainan will be supported by a series of policies and systems for trade, investment and tax facilitation, and various international platforms will be set up successively. Hainan can give full play to the node regional advantages of One Belt And One Road and the new opportunities of building free trade zone (port), and give priority to the development of secondary and tertiary industries. By then, hainan will attract more enterprises to set up factories in the island. Compared with guangxi, enterprises in guangxi may be attracted by preferential tax policies in hainan, so as to move enterprises out of guangxi and set up factories in hainan, so as to enjoy various preferential policies in hainan free trade zone.

\section{SUGGESTIONS OF USING GUANGXI DEVELOPMENT STRATEGY}

TABLE II STRATEGIC SWOT ANALYSIS DIAGRAM

\begin{tabular}{|c|c|c|}
\hline Internal capacity & & Weak point $(\mathrm{W})$ \\
\hline $\begin{array}{l}\text { factor } \\
\\
\text { External } \\
\text { environmental } \\
\text { factors }\end{array}$ & $\begin{array}{l}\text { 1.Guangxi has } \\
\text { a profound } \\
\text { cooperative } \\
\text { relationship } \\
\text { with asean, } \\
\text { and guangxi } \\
\text { has formed a } \\
\text { free } \\
\text { development } \\
\text { route[7]; } \\
\text { 2.Guangxi } \\
\text { enjoys } \\
\text { advantageous } \\
\text { geographical } \\
\text { location, } \\
\text { convenient } \\
\text { trade } \\
\text { transportation } \\
\text { at home and } \\
\text { abroad; }\end{array}$ & $\begin{array}{l}\text { 1.Transportation infrastructure construction and logistics system need to be } \\
\text { improved; } \\
\text { 2.The degree of opening up is at a disadvantage; }\end{array}$ \\
\hline $\begin{array}{c}\text { Opportunities } \\
\text { (O) } \\
\text { 1. The two } \\
\text { places can } \\
\text { strengthen } \\
\text { connectivity, } \\
\text { jointly innovate, } \\
\text { promote the } \\
\text { development of } \\
\text { high-tech } \\
\text { industries, and } \\
\text { adjust the } \\
\text { industrial } \\
\text { structure; } \\
\text { 2. 2.Approp } \\
\text { riate industrial } \\
\text { transfer between } \\
\text { the two places; }\end{array}$ & $\begin{array}{c}\text { S1O1: } \\
\text { increase } \\
\text { investment in } \\
\text { science and } \\
\text { education } \\
\text { industry to } \\
\text { enhance } \\
\text { industrial } \\
\text { innovation } \\
\text { ability; }\end{array}$ & $\begin{array}{l}\text { W2O1: enhance the capacity for coordinated development and deeply cultivate the } \\
\text { asean market; } \\
\text { W1O3: strengthen infrastructure and transportation construction and promote } \\
\text { tourism development }\end{array}$ \\
\hline
\end{tabular}


Table II, cont

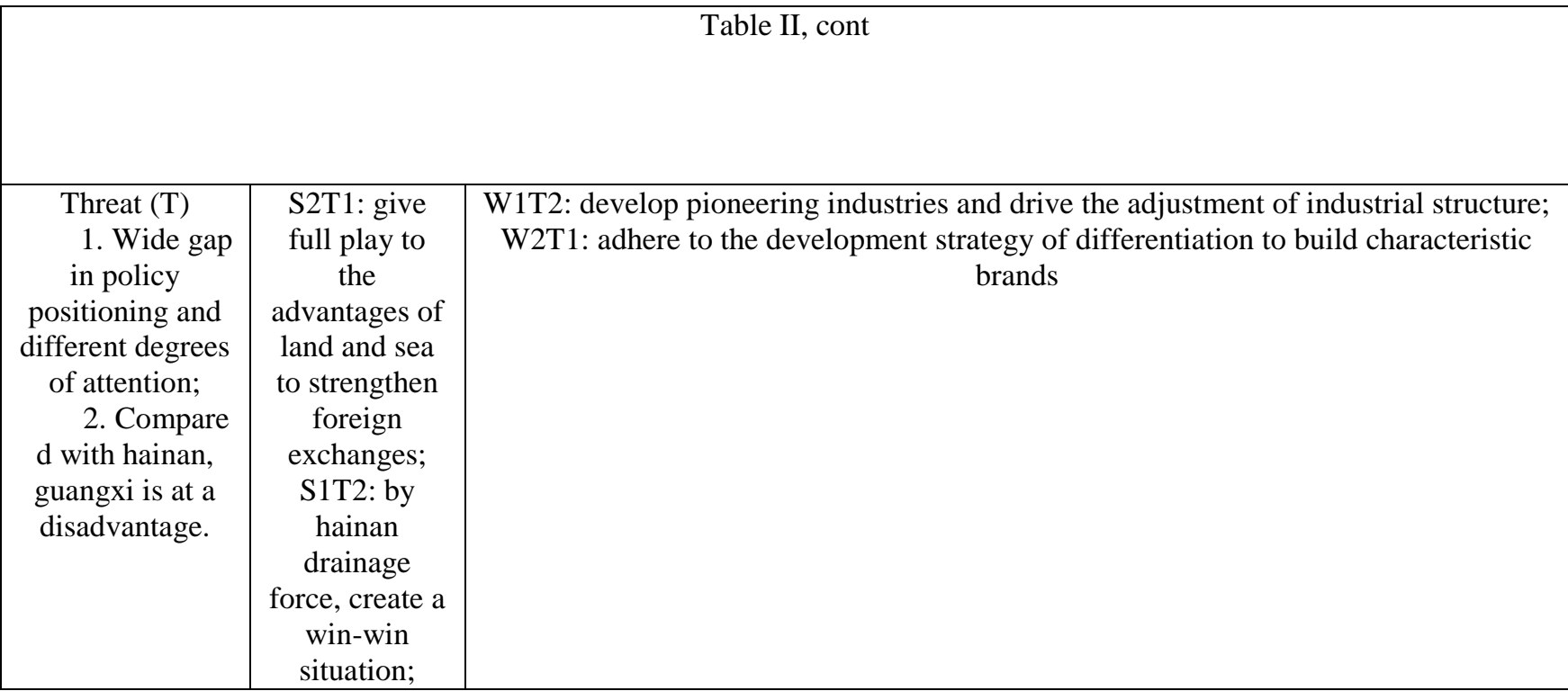

\section{CONCLUSION}

Generally speaking, guangxi should focus on optimizing its industrial structure and promoting industrial upgrading. Make it no longer limited to low-end industries, and increase the support for the development of scientific research, and vigorously introduce talents. We should give full attention to our underdeveloped industries, such as transportation and infrastructure. Of course, on this basis, we should also strive to further promote the development of local tourism and enhance the balanced development of various industries. At the same time, we should make full use of our own advantageous industries. In the process of constantly improving and strengthening the leading industries, we should build local characteristic brands, focus on differentiated development, and form unique local characteristics, so as to turn them into powerful attraction of foreign trade. Guangxi should make full use of its geographical advantage in the geographical center of China and asean, lead by the innovation of opening mechanism, achieve comprehensive breakthroughs in the utilization of foreign capital, import and export trade and foreign direct investment, and assume the historical mission entrusted to guangxi by the national new round of economic development strategic planning.

\section{REFERENCES}

[1] Chen chang. The impact of china-asean free trade area on China's trade [J]. Enterprise guide, 2012.

[2] Chen ce. The overall plan of China (Shanghai) pilot free trade zone approved by the state council [J]. Policy outlook, 2013.

[3] Zhao lifang; Zhou xinsheng. Analysis on the development and upgrading of china-asean free trade area $[\mathrm{J}]$. Foreign trade practice, 2018 ,No.350,27-31.

[4] Lin kunyong. Research on the development strategy of guangxi beibu gulf economic zone under the new opportunities of hainan free trade zone construction [J]. Journal of guangxi university,2018, No. 1999,6672.

[5] Qiu xueqing; Liang yumin. Interaction between hainan free port and guangdong free trade zone [J]. Times economics and trade,2018,No.446,64-66.

[6] The state council. China (hainan) pilot free trade zone overall plan [R].2018.10.

[7] Wu jianxin, zou weizhong et al. Guangxi statistical yearbook -- 2017 $[\mathrm{DB} / \mathrm{OL}]$. Guangxi bureau of statistics. 